\title{
多年性平坦水と垂直構造物のエネルギ一制限型相互作 用による氷荷重の算定法
}

\author{
加藤 一行 1 \\ 1 正会員 近畿大学教授 生物理工学部人間工学科 († 649-6433 和歌山県紀の川市西三谷 930) \\ E-mail:kazkato@waka.kindai.ac.jp
}

\begin{abstract}
水荷重の算定法は，承象の種類と存在の仕方（主に季節）により大きく異なる．構造物の形状のことはさて おき, 水象の種類と存在の仕方で分類したものが. 水荷重シナリオである. 設計的な水荷重を設定する場合, 想定する海域での全ての水荷重シナリオに対して, 水荷重と再現期間の関係を求め, 想定する再現期間で最大 の水荷重を設計上の特定荷重とする. 本研究では, 夏期の多年性平坦水と垂直構造物との相互作用というシナ リオにおける水荷重の算定法を，水象の持っていた運動エネルギーが相互作用後も氷象の運動エネルギーと水 象の破壊によって消費されるエネルギー（クラッシングエネルギー）の和として保存されるという仮定のもと で定式化した。 さらに，その定式化を踏まえると，このシナリオの必要性に関する検討を行わなくてはならな いとの認識に達した．検討を行った結果，遭遇確率が非常に高いと想定される海域以外ではこのシナリオを考 慮する必要は無いとの示唆を得た.
\end{abstract}

Key Words: Arctic structure, Ice load scenarios, Crushing energy

\section{1. 緒言}

北極海沿岸域，オホーツク海沿岸域，サハリン島沿岸 域などは大陸棚が発達しており,豊かな天然資源, 特に, 石油，天然ガスの化石資源が埋蔵されていることが知ら れている.上に挙げたような海域は，季節的に海水に覆 われる海域であり，水海域と総称される．水海域で資源 開発に用いられる海洋構造物を水海構造物と呼ぶ. 水海 構造物を設計する場合, 2 種の海水との相互作用による 外力, これを水荷重と呼ぶ, を考慮しなくてはならない. ひとつは水海構造物の構造設計, すなわち構造部材の配 置や諸寸法を決定するための水荷重（これを局部水荷重 と呼ぶ）である.もう一つは，構造物の全体的な安定性 を評価する水荷重（これを全体水荷重と呼ぶ）である.

全体水荷重の算定には, 季節と 1 年性平坦水とか多年 性リッジとかの水象の種類により異なった相互作用の形 態が想定され，当然その形態により異なった算定法を用 いなくてはならない. どの算定法においても, 関係する 自然環境に起因する設計パラメータが多くあり，それら は一般に確率的にしか把握できないので, 確率論的な考 察によってはじめて全体水荷重が評価できる.

相互作用の形態は次の 3 種に大別できる 1 ).

(a) 駆動力制限型(Limited Driving Force)相互作用

1 年性平坦水に埋め込まれた比較的小さいが厚さの大
きな水象（多年性平坦水や多年性リッジ）が，比較的緩 やかな速度で構造物と遭遇する. このとき接触している 水象の破壊が生ずる前に, 水象背後の相対的に薄い 1 年 性平坦水が，水象との境界面で座屈破壊を起こす（図-1 参照）。したがって,この座屈破壊荷重以上の荷重は構造 物に作用しない.

水荷重の大きさは，主に相互作用を起こす水象の大き さに強く依存する. 当然, 水荷重は水象が大きいほど大 きくなるが, 水象が大きくなると部分的な座屈破壊が起

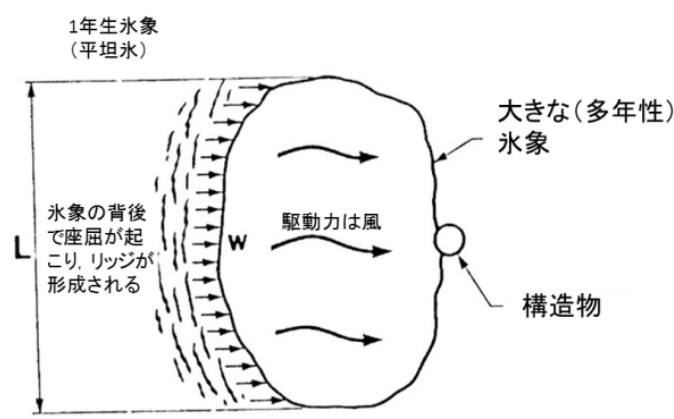

図-1 駆動力制限型(LDF)相互作用の概念図 こる可能性が大きくなる. 1986 年の Amauligak I-65 鉱区における Molikpaq の観測記録 2)にも，比較的大き 
な多年性水象が Molikpaq に止められ，その背後で部分 的な破壊（座屈破壊とは特定されていない）が起こった ことが報告されている. 荷重の算定は形状を単純化して Sodhi の図表 3)を用いるほかに方法が無い.

（b）エネルギー制限型(Limited Energy)相互作用

夏期には比較的小さな多年性水象が独立して運動して いる. 構造物との衝突が起こる (図-2参照) と, 水象が 衝突前に持っていた並進運動エネルギーは，衝突後には 並進運動エネルギー，回転運動エネルギーおよび接触部 の水象の破壊による消費されるエネルギー（クラッシン グエネルギー）により分担される．したがって氷荷重は そのクラッシングエネルギーにより決まる.

この相互作用も Molikpaq の観測記録 2に報告されて いるが，承象の大きさが Molikpaq とさほど変わらず, そのためか顕著な水荷重は記録されていない，衝突部で 水象に局部的なクラッシングが起こったと報告されてい る. 水荷重の大きさは後述するように、相互作用前に水 象の持っている運動エネルギーに強く依存する.

(c) 応力制限型(Limited Stress)相互作用

比較的大きな水象（駆動力が無限とみなせる）が構造 物に接触すると，その接触部で水象が連続的に破壊する (図-3 参照). 水荷重は氷象の破壊荷重で決定される.

この相互作用が一般的と認識され、Molikpaq の観測 記録 2)でも頻繁に報告されている. 垂直構造物の場合は, 水象はクラッシング破壊を起こし，そのクラッシング破 壊荷重が水荷重である. 傾斜構造物の場合は, 水象の曲 げ破壊荷重が氷荷重である。いずれにせよ，水荷重の算 定法は数多く提案されている.

水荷重の算定法は, 水象の種類と存在の仕方（主に季 節)により大きく異なる. 当然構造物の形状によっても, 水象の破壊様式が異なるので水荷重算定法も異なるが, 構造物の形状のことはさておき, 水象の種類と存在の仕 方を分類すると下記のようになる．これを水荷重シナリ オと呼んでいる. 解水期とは冬期と夏期の間であるが, 工学的には定着水がその厚さを減じ始めてから完全に融 解するまでの期間を意味する. 水象の運動はこの間で もつとも活発となる.

北極海では次に列記する 10 種の水荷重シナリオ ${ }^{4)}$ 考慮しなくてはならないと言われている。（）内は頭 文字で表した相互作用の形態である.

冬期の一年性平坦水との相互作用（LS）

冬期の一年性リッジとの相互作用 (LDF)

冬期の多年性平坦水との相互作用 (LDF)

冬期の多年性リッジとの相互作用 (LDF)

解水期の一年性リッジとの相互作用 (LS, LDF)

解水期の多年性平坦水との相互作用 (LS)

解水期の多年性リッジとの相互作用（LS，LDF）

夏期の多年性平坦水との相互作用（LE）
夏期の多年性リッジとの相互作用（LE）

夏期の分割された氷島との相互作用 (LE)

氷海構造物を設計するには，ある再現期間に対応する 水荷重（特定水荷重）を算定しなければならない，基本 的には，上記の氷荷重シナリオでの起こりらる各シナリ オ（例えば，才ホーツク海では 1 年水しか存在しないか ら，1 年水以外のシナリオは考慮する必要はない）にお ける特定水荷重をそれぞれ算定し，それらのうち最大の ものを, 特定水荷重としなくてはならない. 逆に言えば, その海域で想定しなくてはならない全ての水荷重シナリ オにおいて，それぞれのシナリオに対して特定水荷重を 算定できなくてはならない，なぜなら，考慮する海域に よりどのシナリオが支配的であるかをあらかじめ判断す ることは難しいからである. 最良の対応は個々のシナリ 才に対して特定水荷重の算定法, 寸なわち, 再現期間一 水荷重関係の算定法を確立しておくことである.

氷荷重シナリオは，相互作用の形態を考えれば， 3 種 に分類できる．あとは水象の相違だけであるので，基本 的な手法が確立できれば，少しの修正を加えるだけで実 用化できると思われる，そこで，本研究ではエネルギー 制限型の相互作用における再現期間一水荷重関係の算定

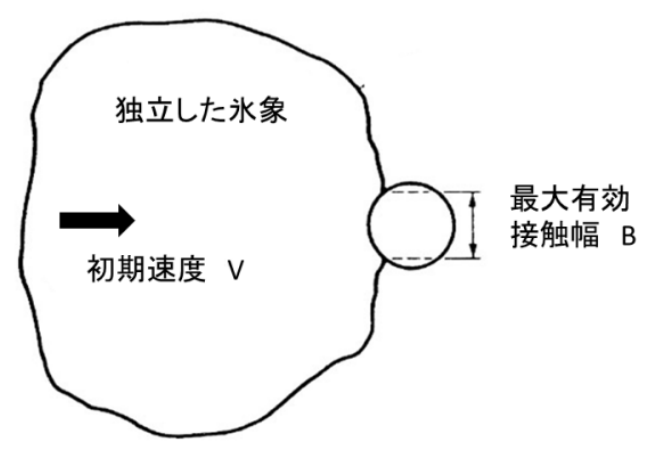

図-2 エネルギー制限型(LE)相互作用の概念図

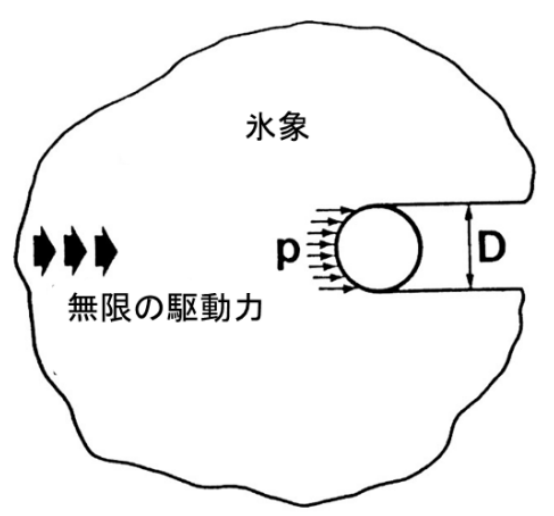

図-3 応力制限型 $(\mathrm{LS})$ 相互作用の概念図 法の根幹部を確立することを目標としている.

対象とする構造物は, 垂直構造物とし, 水象が相互作 
用（衝突）前に持っていた並進運動エネルギーは保存さ れ, 衝突後には並進運動エネルギ一, 回転運動エネルギー および接触部の水象の破壊による消費されるエネルギー

(クラッシングエネルギー）により分担される，と考え て氷荷重モデルを定式化する.

\section{2. 水荷重モデル}

\section{（1）基本仮定}

水荷重モデルを定式化するにあたり下記の仮定を設け る（図-4参照）。

（i）水象は厚さ $(h)$ が一様で直径Dの円形をしている.

（ii）水象の圧縮強度 $\left(\sigma_{c}\right)$ は一様で，接触面においては クラッシング破壊が生ずる.

(iii) 水象は速度 $(V)$ で $x$ 方向に向かって直進し, 離心距 離 $(e)$ で構造物に衝突する.

(iv) 衝突の前後でエネルギーは保存される. 衝突前に 水象が持っていた運動エネルギー $\left(E_{k}\right)$ は, 衝突後の運動 (回転運動を含む) エネルギー $\left(E_{r}\right)$ と水象の局部的破壊 により消費されるエネルギー(クラッシングエネルギー) $\left(E_{c}\right)$ の和で与えられる. すなわち, 次式が成り立つ.

$$
E_{k}=E_{r}+E_{c}
$$

（v）構造物は剛で垂直壁を持ち, 直径d の円形である.

\section{（2）運動方程式}

水象の重心の運動方程式は以下のようになる.

$$
\begin{aligned}
& -F_{x}=\left(1+C_{f}\right) M \ddot{x} \\
& F_{y}=\left(1+C_{f}\right) M \ddot{y} \\
& F_{x} e-F_{y} x_{0}=\left(1+C_{r}\right) I \ddot{\theta}
\end{aligned}
$$

ここに, $F_{x}$ : 接触面における $x$ 方向の力, $F_{y}$ : 接触面 における $y$ 方向の力, $\ddot{x}$ : 水象重心の $x$ 方向加速度, $\ddot{y}$ : 水象重心の $y$ 方向加速度, $\ddot{\theta}$ : 水象重心まわりの回転角 加速度, $M$ : 水象の質量, $I$ : 水象重心まわりの慣性 モーメント, $C_{f}$ : 並進運動の付加質量係数, $C_{r}$ : 回転 運動の付加質量係数である.

運動方程式を 1 回積分すると,

$$
\begin{gathered}
\dot{x}=-\frac{F_{x}}{\left(1+C_{f}\right) M} t+C_{1} \\
\dot{y}=\frac{F_{y}}{\left(1+C_{f}\right) M} t+C_{2}
\end{gathered}
$$

$$
\dot{\theta}=-\frac{F_{x} e-F_{y} x_{0}}{\left(1+C_{r}\right) I} t+C_{3}
$$

となる. $C_{1}, C_{2}, C_{3}$ は積分定数である.

$t=0$ において, $\dot{x}=V, \dot{y}=0, \dot{\theta}=0$ であるとの初期条件 により, 積分定数を定めると, 水象重心の角速度は次式 で与えられる。

$$
\dot{\theta}=-\frac{1}{r_{g}^{2}}\left\{(\dot{x}-V) e-\dot{y} x_{0}\right\}+A
$$

ここで, $r_{g}^{2} \equiv \frac{\left(1+C_{f}\right) I}{\left(1+C_{r}\right) M}$ と置いた. A $e \geq \frac{D}{2}$ での制 限を課すための定数である.

$$
e=\frac{D}{2} \text { のとき, } \theta=\dot{\theta}=0 \text { とすると }, x_{0}=0, \dot{x}=0
$$

であり，接触点まわりの微小な回転角 $\theta$ だけ回転すると 仮定すると, 重心の速度は $\dot{x}=\dot{\theta} e, \dot{y}=\dot{\theta} x_{0}$ であるので, $D / 2=R$ と置くと, 定数 $A$ は次のように定まる.

$$
A=-\frac{V R}{r_{g}^{2}}
$$

結局, $r^{2}=x_{0}^{2}+e^{2}$ であるので, 水象重心の角速度 $\dot{\theta}$ は, 次式で与えられる.

$$
\dot{\theta}=\frac{V(e-R)}{r_{g}^{2}+r^{2}}
$$

\section{(3) クラッシングエネルギー}

これまでに導いてきた諸式を用いると, 衝突後の運動 エネルギー $E_{r}$ は, $C_{f}=C_{r}$ と仮定すると, 次式となる.

$$
\begin{aligned}
& E_{r}=\frac{1}{2}\left(1+C_{f}\right) M\left(\dot{x}^{2}+\dot{y}^{2}\right)+\frac{1}{2}\left(1+C_{r}\right) I \dot{\theta}^{2} \\
& =\frac{\left(1+C_{f}\right) M}{2} \frac{V^{2}(e-R)^{2}}{\left(r^{2}+r_{g}^{2}\right)}
\end{aligned}
$$


衝突前の運動エネルギー $E_{k}$ は,

$$
E_{k}=\frac{\left(1+C_{f}\right) M V^{2}}{2}
$$

であるので，水象の局部的破壊によって消費されるク ラッシングエネルギーは，次式により与えられる.

$$
\begin{aligned}
& E_{c}=E_{k}-E_{r}=\frac{\left(1+C_{f}\right) M V^{2}}{2}\left\{1-\frac{(e-R)^{2}}{r^{2}+r_{g}^{2}}\right\} \\
& =\frac{\left(1+C_{f}\right) M V^{2}}{2}\left\{\frac{\left(\frac{e}{R}-1\right)^{2}}{1+\left(\frac{r}{r_{g}}\right)^{2}}\right\}\left(\frac{R}{r_{g}}\right)^{2}
\end{aligned}
$$

水象への貫入量が大きくないとすると, $r \approx R$ なので, クラッシングエネルギーは, 離心率 $a \equiv e / R$ を導入する と，次式により記述できる.

$$
E_{c}=\frac{\left(1+C_{f}\right) M V^{2}}{2}\left\{\frac{(a-1)^{2}}{1+\left(\frac{r}{r_{g}}\right)^{2}}\right\}\left(\frac{r}{r_{g}}\right)^{2}
$$

氷象の重心まわりの慣性モーメント $I$ は, $I=\frac{R^{2}}{2} M$ であり, 水象への貫入量が大きくないとすると, $r \approx R$ な ので, $\left(r / r_{g}\right)^{2}=2$ となる. これを使うと,

$$
E_{c}=\frac{2\left(1+C_{f}\right) M V^{2}}{2}\left\{\frac{(a-1)^{2}}{3}\right\}=\frac{(a-1)^{2}\left(1+C_{f}\right) M V^{2}}{3}
$$

となる. 承象の質量は仮定により, $M=\frac{\pi D^{2}}{4} h \rho$ である. ここに， $\rho$ は水象の密度である. したがって, クラッシ ングエネルギーは次式により記述できる.

$$
E_{c}=\frac{(a-1)^{2}\left(1+C_{f}\right) \pi D^{2} h \rho V^{2}}{12}
$$

例えば, $C_{f}=0.3, D=500 \mathrm{~m}, h=3 \mathrm{~m}, \rho=800 \mathrm{~kg} / \mathrm{m}^{3}$ とす ると, 離心率 $a$ とクラッシングエネルギー $E_{c}$ の関係は図 -5のようになる.

一方，クラッシングエネルギーは，一般的に，

$$
E_{c}=\int_{0}^{s} F(s) d s
$$

である.ここに, $s$ は構造物の水板中への貫入量である. $F(s)$ は貫入量の関数で表現された氷荷重算定式である.

一般論的には(16)式と(17)式が等しくなるような貫入 量 $s$ を見いだし，その值を $F(s)$ に与えることにより構造 物に作用する氷荷重を見いだし得る.

\section{（4）永荷重モデル}

クラッシング破壊の水荷重算定式はこれまでに数多く 提案されているが，ここでは水海構造物設計ガイドライ

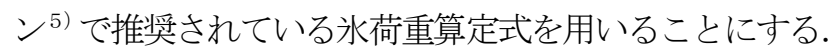
すなわち次式である.

$$
F(B)=C \sigma_{c} h B
$$

ここに, $B$ : 有效接触幅, $C$ : 有効接触幅に依存寸る係 数 $C=0.3 \sim 0.5$, である.

構造物の水板中への貫入量 $S$ 之有効接触幅の関係は, 貫入量が大きくない場合には次式で近似できる（図-6 参 照）。

$$
B=2\left(s d-s^{2}\right)^{1 / 2}
$$

したがって，水荷重算定式は構造物の水板中への貫入 量 $s$ の関数として次のようになる.

$$
F(s)=2 C \sigma_{c} h\left(s d-s^{2}\right)^{1 / 2}
$$

例えば, $C=0.3, \sigma_{c}=2 \mathrm{MPa}, d=50 \mathrm{~m}, h=3 \mathrm{~m}$ のときの貫 入量と水荷重の関係は図-7 のようになる. この曲線は, 小中規模の模型実験で，直線的に切りそろえた氷板に垂 直壁を持った円形構造物を貫入する過程で観察される曲 線を平滑化したものと同様である．貫入が進行すると図

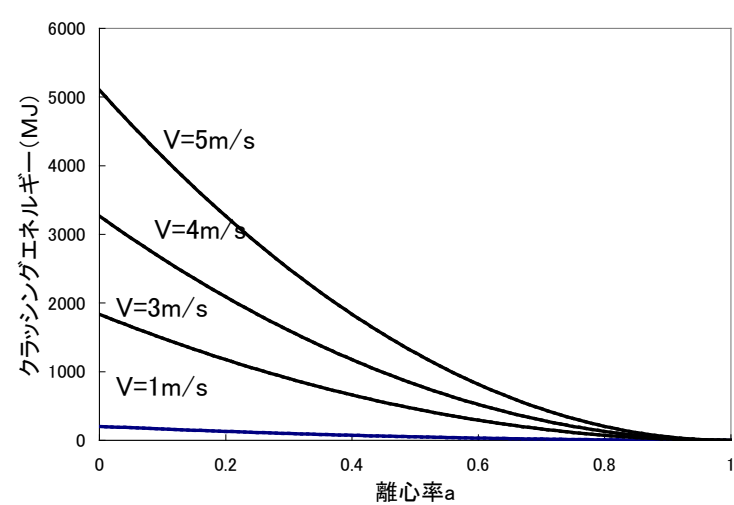

図-5 離心率とクラッシングエネルギーの関係

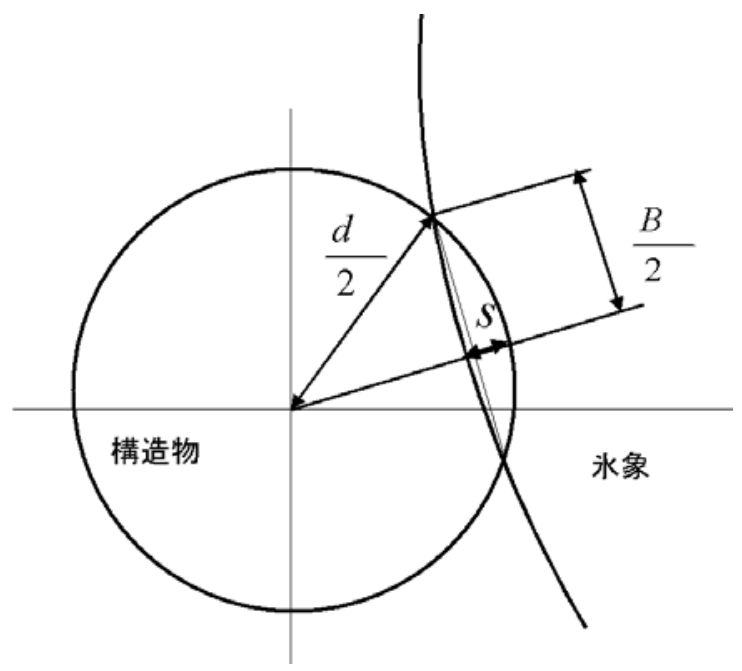

図-6 貫入量と有效幅 
-3に表されているような様相を呈する.

クラッシングエネルギーは(20)式を用いて，次のよう に与えられる.

$$
E_{c}=\int_{0}^{s} F(s) d s=2 C \sigma_{c} h \int_{0}^{s}\left(s d-s^{2}\right)^{1 / 2}
$$

積分を実行すると, 次式が得られる.

$$
E_{c}=2 C \sigma_{c} h\left[\begin{array}{l}
-\frac{-2 s+d}{4}\left(s d-s^{2}\right)^{1 / 2} \\
+\frac{d^{2}}{8}\left\{\frac{\pi}{2}-\arcsin \left(\frac{-2 s+d}{d}\right)\right\}
\end{array}\right]
$$

この(22)式と(16)式が等しくなる貫入量 $s$ を見いだし， それを(20) 式に代入することにより水荷重を算定するこ とができる.

$C_{f}=0.3, D=500 \mathrm{~m}, V=1 \mathrm{~m} / \mathrm{s}, C=0.4, \sigma_{c}=2 \mathrm{MPa}$, $d=50 m, h=3 m$ という条件のもとにおける離心率と水 荷重関係を求めると図-8 を得る. 貫入量 $s$ を, ある離心 率に対して, Newton-Raphson 法により数值解を求め, それより水荷重を算定している.

エネルギーが大きくなり，貫入量が小さいという仮定 が成り立たないことも起きうる. そのようなときには(18) 式で $B=d$ として氷荷重を算定寸る.（18)式に代えて, 多少計算は面倒になるが，クラッシング破壊に対応する 他の水荷重算定式6) を用いてもよい.

\section{（5）遭遇確率}

この種のシナリオでは遭遇確率が再現期間と氷荷重の 関係に対して大きな影響がある。そこで遭遇確率の算定 法を紹介寸る.

氷荷重がある值を超える確率を $q$ とすると、その $q$ と それが起こるまでの年数 (再現期間) $R$ との間には、次 の関係がある。

$$
R=\frac{1}{(1-q) \mu}
$$

ここに、 $\mu$ は対象としている承象の 1 年あたりの遭遇回 数である。

対象としている水象の 1 年あたりの遭遇回数 $\mu$ は構 造物と氷象の遭遇確率 $p(c)$ と対象としている季節の長 さの積として算定することができる. 遭遇確率 $p(c)$ は単 位時間あたりの水象と水象と構造物の通過面積から、次 式により算定する。

$$
p(c)=v\left(D_{m}+d\right) V_{m}
$$

ここに、 $v$ は氷象の空間的密度(単位面積あたりの個数)、 $D_{m}$ は水象直径の平均值、 $V_{m}$ は水象速度の平均值である。

\section{3. 検討 —このシナリオは必要か? -}

前章で導出した氷荷重の算定法は, 構造物, 承象とも
土木学会論文集B3 (海洋開発), Vol. 69, No. 2, I_1186-I_1191, 2013.

円形であるなど種々の単純化がなされているが、クラッ シングエネルギーの算定という観点から許容されると考 えられる。

氷荷重が大きくなるのは, クラッシングエネルギーが 大きいときであるが、氷荷重はクラッシングエネルギー に比例するわけではない，貫入量が構造物の半径以上に なると, 水荷重はどんなに貫入量が増えても、寸なわち クラッシングエネルギーがどんなに増大しても，(18)式 で $B=d$ として算定した氷荷重の值となる。

(18)式で $B=d$ として算定した水荷重の值は、冬期の 多年性平坦水との相互作用シナリオおよび解水期の多年 性平坦水との相互作用シナリオでのクラッシング破壊に 対応する水荷重モデルと同じ表式である. 他の水荷重算 定式を採用した場合でも，クラッシングエネルギーが大 きいときの水荷重算定式は冬期の多年性平坦水との相互 作用シナリオおよび解水期の多年性平坦水との相互作用 シナリオ（以下，冬期のシナリオ）でのクラッシング破 壊に対応する水荷重算定式と同じである。氷荷重算定式 が(18)式であるとして，冬期のシナリオとの諸パラメー タの相違に対して考察を加えよう.

速度は冬期のシナリオに比べてこのシナリオの方が大 きいと考えられる。これは，このシナリオにおいては， クラッシングエネルギーが大きくなることを意味し，他 のパラメータが同じならば, 氷荷重は相方のシナリオで 等しいということになる.

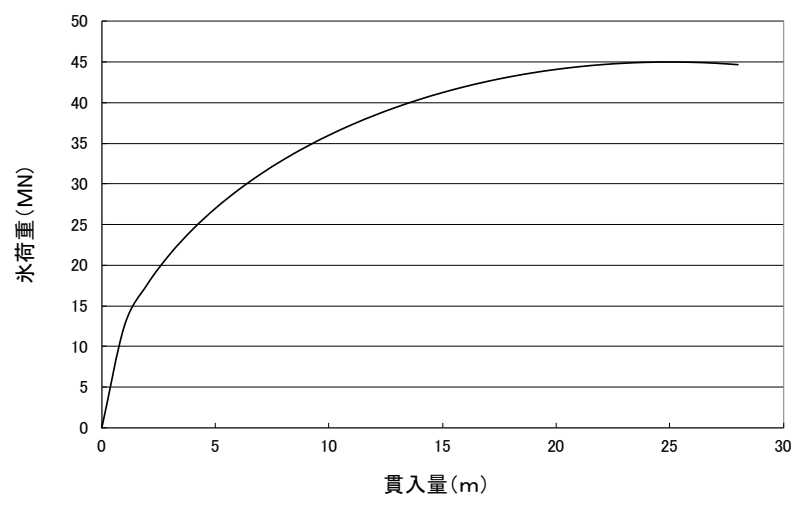

図-7 貫入量と水荷重の関係

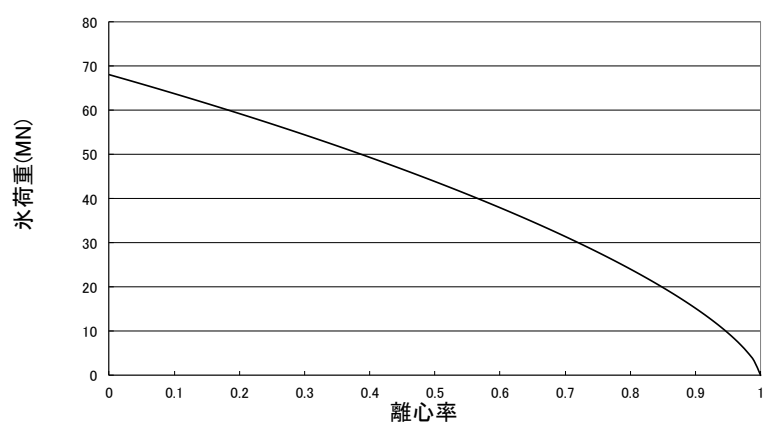

図-8 離心率と水荷重の関係 
水の強度は，このシナリオの方が，温度が高く，塩分 濃度が低いと予想されるから，冬期のシナリオの方が少 し大きいと予想される.

水厚は, 冬期のシナリオでは水象が成長過程にあり、 このシナリオでは融解過程にあるので，冬期のシナリオ の方が大きい可能性が高いと考えられる.

氷荷重に大きな影響を与えるパラメータは離心率で ある。冬期のシナリオでは離心率はパラメータとはなら ない.このシナリオでは離心率は 0 から 1 の間であり、 離心率の大きな相互作用ではクラッシングエネルギーは 構造物の半径以上の貫入量を得るほどには大きくならな い.したがって，水荷重は他のパラメータが等しいとし ても冬期のシナリオでのそれ以下である.

モンテカルロシミュレーションを行うまでもなく，同 じ再現期間に対する水荷重は，このシナリオに対するも のが冬期のそれを上回る可能性は限りなくゼロに近いと 思われる。

このシナリオに対する氷荷重が冬期のそれを上回る ことがあるとすれば，冬期の遭遇確率が非常に低く、夏 期での遭遇確率が非常に高い海域を想定したときである。

上記のような海域以外では、夏期の多年性平坦水との 相互作用シナリオを考慮する必要は無いと強く示唆され る.構造物が傾斜構造物であっても同様である.さらに, 算定法は定式化していないが，夏期の多年性リッジとの 相互作用シナリオも考慮する必要が無いと示唆される.

\section{4. 結語}

夏期の多年性平坦水との相互作用シナリオにおける水 荷重の算定式を定式化した。この定式化ではクラッシン
グエネルギーが大きいと応力制限型の相互作用となると している.これについては観察された例が無く確証はな いが，氷象の持つエネルギーが非常に大きい冬期，解水 期には応力制限型の相互作用が観察されているので，ま ず誤りはないと考えている.したがって，冬期の水象と の遭遇確率が非常に低く、夏期での遭遇確率が非常に高 い海域を例外として，このシナリオを考慮する必要が無 いことが強く示唆されると結論を得た。この定式化は多 年性水板を対象としているが，同様の示唆は多年性リッ ジに対しても得られると考えられる．あるシナリオを考 慮する必要が無いことを明らかにすることは，将来の手 間を省くことになり，大きな貢献であると考える.

\section{参考文献}

1) International Standard Organization: ISO 19906 petroleum and natural gas industries - arctic offshore structures, pp.150, ISO, 2010.

2) Gulf Canada Resources Ltd.: Dynamic ice/structure interaction with the Molikpaq at Amauligak I-65, Gulf Canada Resources Ltd , 1989.

3) Sodhi, D.S. and Hamza, H.E.: Budking Analysis of semi-finite ice sheet, Proceedings Forth Intermational Conference on Port and Ocean Engineering under Arctic Conditions, vol.1, pp.593-604, 1977.

4) 加藤一行 : 水海構造物の設計水荷重推定システム. 石川 島播磨技報 第30巻 第1号 pp.8-12, 1990.

5）水荷重基礎研究委員会：水海構造物設計ガイドライン 海洋石油開発技術調査 極限海域における海洋構造物の 基礎調査研究 海洋構造物に及ぼす水荷重に関する研究 成果報告書（平成5 12 年度）, pp.49，（社）日本海洋 開発産業協会, 2001.

6）加藤一行 : 水荷重推定式の実機計測データを用いた評価 一大型水海構造物を対象とした一土木学会論文集 B3（海 洋開発）vol.68, No.2, pp.1043-1048， 2012.

\title{
CALCULATION OF AN ICE LOAD DURING A LIMITED ENERGY
}

\author{
INTERACTION BETWEEN A MULTI YEAR FLOE AND A STRUCTURE
}

\section{Kazuyuki KATO}

One of 10 scenarios to be considered for planning and designing an arctic structure is an interaction between a multi year ice floe and a structure during summer. In this interaction the ice floe has limited energy. During winter and break-up season, ice floes seem to have infinite energy, then the limited stress scenario is applied. In this limited energy scenario, the ice floe has linear kinetic energy before the interaction. After the interaction, that energy will be conserved as the sum of kinetic energy of the floe and crushing energy which would consumed during ice crushing. The crushing energy is the difference of kinetic energies between before and after the interaction. The crushing energy can also be obtained by integrating the ice load - penetration distance relationship. By equating those two crushing energies, the penetration distance can be obtained. The ice load can be calculated from the ice load - penetration distance relationship. However, this formulation strongly suggests that this scenario is not needed unless the encounter rate is extremely high during summer and extremely low during winter and break-up season. 